特集記 事

遺伝資源を利用したダイズの開花および伸育性に関する分子遺伝学的研究

阿部 純

北海道大学大学院農学研究院, 北海道札幌市, $\bar{\top} 060-8589$

\title{
Molecular-genetic study on flowering and growth habit of soybean by use of germplasm
}

Jun Abe

Research Faculty of Agriculture, Hokkaido University, Sapporo, Hokkaido 060-8589

キーワード

ダイズ，開花，非感光性，伸育性，遺伝資源，分子遺伝学的機構

\section{1. はじめに}

ダイズは赤道直下から北緯 50 度に亘る幅広い緯度環境 の下で栽培される作物であり，この広域適応性には開花 早晚性に関わる数多くの遺伝子が関与している. 特に, 短日植物であるダイズが高緯度地域の長日下で開花・登 熟するには感光性の低下または欠落（非感光性）が欠か せない。北海道のダイズ栽培は明治に始まるが，生育初 期の冷涼で日長が長い北海道の環境に適応したダイズが 非感光性遺伝資源として広く利用されている. 本研究は, 北海道のダイズ品種の開花特性の遺伝機構の解析を端緒 として，世界各地の非感光性ダイズの開花の遺伝機構と 責任遺伝子の多様性の解析, シロイヌナズナの FLOWERING LOCUS T のダイズオルソログの特定と機能 解析，伸育性に関する分子機構の解析など，ダィズの開 花ならびに伸育性に関する研究を国内外の研究者らとと もに進めてきた. 本稿では, これまでの研究の経緯とダ イズの開花や伸育性に関する最近の研究を簡単に紹介し たい．個々の開花遺伝子の機能や多様性の詳細ならびに 遺伝子間の発現ネットワークについては Watanabe et al. （2012）またはCao et al.（2017）の総説を参照していた だければ幸いである。

\section{2. 北海道極早生系統の非感光性に関わる遺伝 機構}

ダイズの非感光性は，古くから蛍光灯や白熱灯を用い て人為的に作出された長日条件で評価されてきた。研究

2018 年 10 月 17 日受領 日本育種学会賞受賞 (第 136 号) 2018 年 11 月 9 日 J-STAGE 早期公開

Correspondence: jabe@res.agr.hokudai.ac.jp
の当初，すでに人為長日下での開花に関わる二つの遺伝 子 (E3 およびE4) が特定されていた（Buzzell 1971, Buzzell and Voldeng 1980, Saindon et al. 1989). E3 座は赤色光の豊 富な蛍光灯で作出された長日（Fluorescent long day; FLD）下での開花に関与し，E3 は開花を抑制し e3 は開 花を誘導する。 一方 $E 4$ 座は $e 3$ の下で遠赤色光の豊富な 白熱灯で作出された長日（Incandescent long day; ILD）下 での開花に関与し，E4 は開花を抑制し e 4 は開花を誘導 する。

北海道の在来および育成品種の多くはFLDに対しては 不感受性を示すが，ILD に対する反応は品種系統間で異 なる. ILD 不感受性の「大谷地 2 号」と感受性の「十勝 長葉」ならびにカナダ品種「八ロソイ」のe 3 に関する準 同質遺伝子系統（NIL）との交雑後代の遺伝解析から,

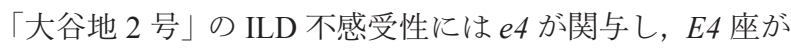
I 連鎖群（染色体 20）の長葉およびエンドペプチターゼ アイソザイム遺伝子と連鎖することがわかった（Abe et al. 2003a). 北海道の ILD 不感受性系統には, 「大谷地 2 号」とその近縁な系統に加えて, それらとはアイソザイ ムやSSR の遺伝子型で異なる系統が存在する。前者の 「三春大豆」と後者の「坂本早生」の交雑後代では ILD 感受性個体が分離し, ILD 不感受性の遺伝機構が両者で 異なっていた。 DNA マーカーを用いた解析から，「三春 大豆」の ILD 不感受性には「大谷地 2 号」同様に e4 が, 「坂本早生」の不感受性にはダイズの開花に大きな効果を もつE1 座かまたはそれと密接に連鎖する遺伝子座の劣 性遺伝子が関与することがわかった（Abe et al. 2003b, Liu and Abe 2010).

\section{3. $E 4$ の責任遺伝子の特定}

$E 4$ の解析を進めていた 2000 年当初は全ゲノムシーク 
エンス情報もなく，また BAC ライブラリーのよらなゲノ ムリソースも持ち合わせていなかった。そこでE4の予 想される機能をもとに，その責任遺伝子の候補として遠 赤色光の受容体であるフィトクローム A（PHYA）に焦点 を当て，E4 座に関する NIL からダイズのPHYA 遺伝子 (SOYPHYA）を単離して塩基配列を解析した。 その結果， SOYPHYA（GMPHYA1）に加えてそのホモログである GmPHYA2 が単離された. 特にe4の NIL から単離された GmPHYA2 はコピア様レトロトランスポゾン (SORE-1) が挿入された機能喪失型の遺伝子であった。 マッピング の結果，GMPHYA2 はE4 と同座であったことから， GmPHYA2 がE4 の責任遺伝子であると結論づけた（Liu et al. 2008). 一方，SOYPHYA はE4 座の同祖領域にマッ プされ, SOYPHYA とE4 は同祖遺伝子であった. $e 4$ は $E 4$ に比べて遠赤色光の下で胚軸や節間が徒長しやすい性質 をもつ。しかしe4の NIL に拈いてもPHYAの機能は完 全には消失して抢らず，SOYPHYA がE4 の遠赤色光に対 する応答に助長的に作用していると思われる。 また $e 4$ 特 異的な DNA マーカーを用いた解析から，SORE-1 の挿入 された $e 4$ はアジアの中でも本州北部や北海道のダイズに 特異的であることがわかった（Kanazawa et al. 2009）.

\section{4. ダイズの $F T$ オルソログ}

2007 年, シロイヌナズナの FLOWERING LOCUS T （FT）とイネの HEADING DATE 3a が葉で生産された のち茥頂へ輸送されて開花を誘導するフロリゲンとして の役割を担らことが明らかにされた。そこで，ダイズの $F T$ オルソログの特定を試みた。 FTの cDNA 配列を参照 にしたDNA データベースの検索と遺伝子の単離および 塩基配列の解析，ならびに BAC ライブラリ一のスクリー ニングと塩基配列の解析から，5 カ所のゲノム領域にそ れぞれ 2 個ずつタンデムに配列した 10 個の FTオルソロ グ (GmFT1a, GmFT1b, GmFT2a, GmFT2b, GmFT3a, GmFT3b, GmFT4, GmFT5a, GmFT5b および GmFT6) を特定することができた（表 1)。GmFT1a と GmFT1b は GmFT6 㧊よび GmFT4 と, GmFT3a と GmFT5a は GmFT3b および $G m F T 5 b$ とそれぞれ同祖的な関係にあり, GmFT2a と $G m F T 2 b$ の同祖領域には第 4 エキソンのみをもつキメ ラ遺伝子 $G m F T 2 c$ が存在した。 これらのらち，GmFT2a
と GmFT5a の発現はE3 およびE4 の制御下にあり，他の 遺伝子に比べて短日で強く誘導され長日で抑制されるこ と，また $35 \mathrm{~S}$ プロモーターを用いた異所的発現によりシ ロイヌナズナ Col-0 の開花を促進したことから，GmFT2a と GmFT5a がダイズの主要な FTオルソログであると結 論づけた（Kong et al. 2010）。これにより，ダイズの開花 遺伝子の機能を FTオルソログの発現を通して検討する ことが可能になった。 その後, ダイズの FTオルソログ の研究は多くのグループによって進められ，1）過剒発現 （Nan et al. 2014, Sun et al. 2011）扣よびRNA 干渉（Guo et al. 2015）により GmFT2a と GmFT5a の開花誘導の機能 がダイズでも検証され，2）栽培系統では機能を哀失して いる GmFT2c が野生系統では機能遺伝子 (GSFT2c) とし て存在すること（Wu et al. 2017），3）シロイヌナズナ Col-0 での異所的発現解析から, GmFT2a と GmFT5a に加 えて 5 個のオルソログ (GmFT2b, GmFT2c, GmFT3a, $G m F T 3 b$ 特よび GmFT5b) が FT の機能をもち，一方 GmFT4 が Col-0 の開花を抑制すること（Fan et al. 2014, Thakare et al. 2011, Wang et al. 2015, Wu et al. 2017, Zhai et al. 2014), 4) GmFT1a は GmFT2a や GmFT5a に拮抗的に 作用してダイズの開花を抑制し，晚生系統の開花制御に 関与すること（Liu et al. 2018），などが現在までに明らか にされている.

\section{E9 およびその他の開花遺伝子の責任遺伝子}

ダイズの開花に関与する遺伝子として，これまでに $E 3$ と $E 4$ を含む 11 個の主働遺伝子 $(E 1 \sim E 10, J)$ が報告さ れている. これらのらち北海道のダイズに見出された $E 9$ 座の劣性遺伝子の分子機構を解析した。

E9 は，北海道のダイズ育成系統と野生ダイズの交雑 RIL 集団で分離した開花 QTL（Liu et al. 2007）の遺伝的 解剖から特定された（Kong et al. 2014）。後述のE6 およ び $J$ 除き，多くの開花遺伝子が劣性で早生をもたらす のに対して，E9は劣性対立遺伝子が晚生をもたらす. 北 海道品種「トヨムスメ」は $e 9$ と後述する $E 1$ 座の機能表 失型遺伝子 $e 1-n l$ をもち, $E 9$ と後述の $e 1-a s$ をもつ「八口 ソイ」との交雑後代では両遺伝子座の分離により開花に 大きな変異が生じる。ファインマッピングと候補遺伝子 の塩基配列および発現解析の結果, E9 は GmFT2 $a$ を支配

表 1. ダイズ $F T$ オルソログとそれらの連鎖および同祖関係

\begin{tabular}{lccc}
\hline \hline 連鎖群/染色体 & $F T$ オルソログ & 連鎖群/染色体 & \multirow{2}{*}{$F T$ オルソログ } \\
\hline LG-G/Chr18 & $G m F T 1 a$ & LG-A2/Chr08 & GmFT6 \\
\hdashline$-19 m F T 1 b$ & $G m F T 3 a$ & LG-L/Chr19 & GmFT4 \\
LG-J/Chr16 & $G m F T 5 a(q D T F-J)$ & GmFT5b \\
\hdashline LG-J/Chr16 & $G m F T 2 a(E 9)$ & LG-D1b/Chr02 & GmFT2c/GsFT2c \\
\hline
\end{tabular}

$F T$ オルソログは各染色体領域に 2 個ずつタンデムに配列しており, 表中の同じ列に ある $F T$ オルソログが同祖的な関係にある。 
し, e9 はイントロンに挿入されたSORE-1 による発現低 下型の変異体であることがわかった（Zhao et al. 2016）. $e 9$ と $e 1-n l$ は現在の北海道道東地域で栽培されるダイズ 品種の開花特性を特徵づける遺伝子であり, 樺太に定着 した極早生系統に由来する。 $e 9$ は $e l-n l$ の早生性を押さ えて栄養生長を確保する役割を担っている.

$E 4$ および $E 9$ を除くその他の遺伝子のうち，開花に大 きな効果をもつ $E 1, E 2$ 预よび $E 3$ の責任遺伝子は千葉大 学 (後に農業生物資源研究所) の原田久也博士らのグルー プにより，また短日下での開花早晚性に関わる $J$ の責任 遺伝子は中国科学院のグループにより明らかにされた.

$E 1$ は DNA 結合に関わる B3 様ドメインをもつ転写因 子と考学られ，GmFT2 $a$ 和よび $G m F T 5 a$ の発現を抑制し て開花を遅らせる (Xia et al. 2012). 塩基配列解析の結 果, 従来の劣性対立遺伝子 $e 1$ はアミノ酸置換により核移 行能力が低下した機能低下型（el-as）であり，新たに一 塩基欠失 $(e 1-f s)$ 预よび $E 1$ を含むゲノム領域の欠失 (e1$n l)$ による機能喪失型の対立遺伝子が見出された。特に $e 1-f_{s}$ は「坂本早生」で見出された変異体であり, その ILD 不感受性には el-fs が関与すると考兄られた.

E2 はシロイヌナズナの GIGANTEA（GI）のダイズオル ソログ（GmGIa）であり（Watanabe et al. 2011），E3 はE4 同様に PHYA 遺伝子（GMPHYA3）を支配していた (Watanabe et al. 2009). E3 は赤色光に応答する遺伝子で あり, 遠赤色光への応答に関わる $E 4$ とはPHYA の機能 に関して互いに分化している. GmPHYA3 には同祖遺伝 子 GmPHYA4 が存在する. GmPHYA4 は全ゲノムシークエ ンス解析に用いられた「Williams 82」を含む栽培系統で は第 3 エキソンが久失した機能喪失型の遺伝子であるが, 野生系統には機能型の GmPHYA4 が存在することが報告 されている (Li et al. 2014).

$J$ は，光のシグナルを調節して光周期反応を制御する シロイヌナズナの EARLY FLOWERING 3 (ELF3) のダイ ズオルソログであり，E1 のプロモーターに作用して短日 下でその発現を抑制する（Lu et al. 2017）。劣性対立遺伝 子 $j$ はフレームシフト突然変異による機能喪失型遺伝子 であり，E1 の発現を抑制することができず，短日下にお いてもE1 が発現して開花が抑制される。同じく短日下 での開花早晚性に関わる $E 6$ は $J$ と密接に連鎖している （Li et al. 2017）。横田ら（2018）は，e6を有するブラジル 品種「Paranagoiana」のELF3 がコピア様レトロトランス ポゾンの挿入による機能喪失型遺伝子であることを明ら かにし，e6 と j は同座の異なる劣性対立遺伝子であると 指摘している.

\section{6. 光中断による開花抑制機構と光による E1 の 発現制御}

ダイズは，ガーナーとアラードによる光周性の発見の みならず，ドイッの科学者ビュニングによる光周性の外
的符号モデルの構築にも深く関わった植物である. ダイ ズの開花は，凡そ 24 時間の概日リズムの中で，一定の明 期 (8 時間) 飞続く暗期の後の明期または暗期中の光中 断が最初の明期と同調するよらに与えられると促進され， それより半日ずれて与兄られると抑制される。 ダイズの 開花関する主要な遺伝子 $(E 1 \sim E 4)$ の責任遺伝子と主 要な $F T$ オルソログが特定されたのを機に，ダイズの開 花に括ける光応答の機構を光中断実験や日長变換実験に より検討した，その結果，光中断による開花の抑制には $E 3$ 打よび $E 4$ 亿制御された $E 1$ が関与し，E2 は関与しな いこと，またウイルス誘導ジーンサイレンシング解析か らE1の二つの同祖遺伝子（E1 様遺伝子, ElLa 抢よび $E 1 L b ）$ も $E 1$ 同様に光中断による開花抑制に関与するこ とが明らかとなった（Xu et al. 2015）。E1 および E1 様遺 伝子は, 長日条件に沶いて朝方と夕方の二つの時間帯に 急峻なピークをもつ独特の発現を示す (Xia et al. 2012, Xu et al. 2015). それらの発現は光の有無に強く依存し, 18 時間日長条件で栽培した個体の消灯前 6 時間の明期を暗 期に置き換えると, 前日まで観察されていた夕方の発現 と同時に翌朝の発現が消失する。 この反応は可逆的であ り，置き換えた暗期を明期に戻すと夕方の発現とともに 翌朝の発現が復帰する（Xu et al. 2015）。ビュニングらが 観察した光照射のタイミングに対するダイズの応答には $E 1$ および $E 1$ 様遺伝子の概日リズムと光に依存した発現 機序が関与すると思わ机る。前述の上らに, E1 の発現に はELF3 が関与しているが, $E 1$ の発現制御機構が明らか になればダイズの光周期反応をより良く理解することが 可能になると期待している.

\section{ILD 不感受性の遺伝的多様性}

ILD 不感受性は, 北海道のみならず, 東北地方（岩手 県拈よび青森県）や中国東北地方，極東ロシア抒よび東 欧から導入された品種・系統にも存在する。 これらにつ いて $E 1 \sim E 4$ の塩基配列を解析したところ，新たに $E 1$ 座 に 1 個, E3 座に 2 個, E4 座に 4 個の機能喪失型対立遺 伝子が観察された（Tsubokura et al. 2013, 2014, Xu et al. 2013)。したがって, ダイズの非感光性は, これら 3 遺伝 子座で生じた機能喪失型対立遺伝子を利用しながら, 様々な地域で繰り返し生じてきたことが明らかとなった。 対立遺伝子の機能をもとに分類すると, ILD 不感受性系 統の多くは $E 3$ 打よび $E 4$ の機能喪失型かまたは $E 1$ の機 能喪失型であったが，これらの遺伝子座に関して ILD 感 受性の遺伝子型 (e1-as/e3/E4) をもつ系統も存在した (Xu et al. 2013). 検定交雑後代の遺伝解析から, これらの ILD 不感受性には $G m F T 5 a$ の発現上昇型の対立遺伝子 ( qDTF-J-ef) やE ElLb の機能喪失型対立遺伝子が関与して いた（朱ら 2017， Takeshima et al. 2016）。 


\section{8. 伸育性遺伝子 Dt1 の特定と機能解析}

ダイズの伸育性に関与する遺伝子として古くから D t 1 とDt2 が知られている (Bernard 1972)。Dt1 は無限伸育 性を， dt 1 は有限伸育性を支配し，Dt2 は無限伸育性 (Dt1/-）の下で主茥節の分化を止めて半有限性をもたら 于.

$D t 1$ の候補遺伝子として花序分裂組織の維持に関わる シロイヌナズナの TERMINAL FLOWER1（TFL1）に着目 し，Dt1 とdt1 に関する NIL から二つの TFL1 オルソログ (GmTFL1a および GmTFL1b) を単離した.これらのらち 茎頂で発現する $G m T F L 1 b$ の塩基配列に系統間に非同義 置換を含む塩基多型が観察された。マッピングの結果， $G m T F L 1 b$ は D 1 と共分離し, さらに無限伸育系統由来の $G m T F L 1 b$ のプロモーターを含む遺伝子領域を有限伸育品 種「カリユタカ」に形質転換したところ茥頂が無限伸育 性を示したこと，またウイルス誘導ジーンサイレングに より無限伸育品種の GmTFL1b の発現を低下させたとこ ろ茎頂の無限伸育性が抑えられたことから，GmTFL1b が Dt1 であると結論づけた（Liu et al. 2010）。Dt1 座にはdt1 に加えてそれとは異なる 3 個のミスセンス变異による有 限伸育性遺伝子が発見されている（Tian et al. 2010）.

菱頂におけるDt1 の発現は, 有限伸育系統では開花誘 導とともに消失するが, 無限伸育系統では開花誘導後も 一定期間持続する（Liu et al. 2010, Xu et al. 2013）. 長日 下での Dt1 の発現は開花遺伝子の遺伝子型に影響され, 早生の遺伝子型で早く消失し，その結果茥頂の無限伸育 性が早く止まる（Xu et al. 2013）。主茎節数は，莢数を介 して最終収量に直接影響することから，なぜ有限型で開 花誘導に伴い Dt1 の発現が急速に消失するのか, 今後の 検討課題である.

$D t 2$ の責任遺伝子は，米国パデュー大学の Jianxin Ma 博士らのグループによって同定された. Dt2 は APETALA1/ SQUAMOSA サブファミリーに属する MADS ボックスタ ンパク質であり（Ping et al. 2014），シロイヌナズナの SUPPRESSOR OF OVEREXPRESSION OF CONSTASNS1 （SOC1）のダイズオルソログ $\mathrm{GmSOC1a}$ と二量体を形成 してDt1のプロモーターに結合し，その発現を抑制する (Liu et al. 2016). Dt2 と dt2 の茥頂の相転換に及ぼす効果 の違いは開花誘導に伴ら発現機序の違いに起因すると考 えられているが，その原因となる多型は特定されていな い(Ping et al. 2014). ダイズ栽培に拈ける重要性から, $D t 2$ 対立遺伝子間の機能の差異をもたらす DNA 多型の特 定が望まれる.

\section{9. おわりに}

ダイズの開花や伸育性に関与する遺伝子の責任 DNA 多型が少しずつ明らかにされつつある。特に，世界各地 で栽培されるダイズ品種の $E 1 \sim E 4$ の遺伝子型が DNA 情
報を利用して特定されており，ダイズの地域適応におけ るこれらの遺伝子の重要性をらかがい知ることができる. しかし，これら 4 遺伝子ならびに新たに同定された遺伝 子の DNA 情報だけでは説明できない開花早晚性の変異 が存在して和り，それらの変異に介在するDNA 多型の 特定が望まれる。特に, 開花や伸育性は品種の適応性や 収量性に直接関わることから, 今後それらの分子遺伝学 的な機構の理解がさらに進み，それらの DNA 情報が栽 培育種現場で応用されることを期待している.

\section{謝 辞}

本研究は, 遺伝実験のための交配, 分離集団の調査, マッピング， BACクローンのサーベイとその塩基配列の 解析, ウイルス誘導ジーンサイレンシング解析, 形質転 換を用いた相補実験など，植物遺伝資源学研究室ならび に関連研究室の教員および学生諸君, ならびに国内外の 多くの研究者との共同研究として実施してきたものであ る．研究に携わっていただいた多くの方々に深く感謝申 し上げます。

\section{引用文献}

Abe, J., O.K. Han, K. Komatsu and Y. Shimamoto (2003a) Soybean Genet. Newsl. 30

Abe, J., D.H. Xu, A. Miyano, K. Komatsu, A. Kanazawa and Y. Shimamoto (2003b) Crop Sci. 43: 1300-1304.

Bernard, R.L. (1972) Crop Sci. 12: 235-239.

Buzzell, R.I. (1971) Can. J. Genet. Cytol. 13: 703-707.

Buzzell, R.I. and H.D. Voldeng (1980) Soybean Genet. Newsl. 7: 26 29.

Cao, D., R. Takeshima, C. Zhao, B. Liu, J. Abe and F. Kong (2017) J. Exp. Bot. 68: 1873-1884.

Fan, C., R. Hu, X. Zhang, X. Wang, W. Zhang, Q. Zhang, J. Ma and Y. Fu (2014) BMC Plant Biol. 14: 9.

Guo, G., K. Xu, X. Zhang, J. Zhu, M. Lu, F. Chen, L. Liu, Z.Y. Xi, A. Bachmair, Q. Chen et al. (2015) PLoS One 10: e0136601.

Kanazawa, A., B. Liu, F. Kong, S. Arase and J. Abe (2009) J. Mol. Evol. 69: 164-175.

Kong, F., B. Liu, Z. Xia, S. Sato, B. Kim, S. Watanabe, T. Yamada, S. Tabata, A. Kanazawa, K. Harada et al. (2010) Plant Physiol. 154: $1220-1231$.

Kong, F., H.Y. Nan, D. Cao, Y. Li, F. Wu, J. Wang, S. Lu, X. Yuan, E.R. Cober, J. Abe et al. (2014) Crop Sci. 154: 1220-1231.

Li, X., F. Chao, M. Xu, F. Zhang, S. Lu, H. Nan, T. Su, S. Li, X. Zhao, L. Kong et al. (2017) Crop Sci. 7: 2547-2554.

Li, Y.H., G. Zhou, J. Ma, W. Jiang, L.G. Jin, Z. Zhang, Y. Guo, J. Zhang, Y. Sui, L. Zheng et al. (2014) Nat. Biotechnol. 32: 10451052.

Liu, B., T. Fujita, Z.H. Yan, S. Sakamoto, D.H. Xu and J. Abe (2007) Ann. Bot. 100: 1027-1038.

Liu, B., A. Kanazawa, H. Matsuura, R. Takahashi, K. Harada and J. Abe (2008) Genetics 180: 995-1007.

Liu, B. and J. Abe (2010) J. Hered. 101: 251-256.

Liu, B., S. Watanabe, T. Uchimiya, F. Kong, A. Kanazawa, Z. Xia, 
A. Nagamatsu, M. Arai, T. Yamada, K. Kitamura et al. (2010) Plant Physiol. 153: 198-210.

Liu, W., B. Jiang, L. Ma, S. Zhang, H. Zhai, X. Xu, W. Hou, Z. Xia, C. Wu, S. Sun et al. (2018) New Phytol. 217: 1335-1345.

Liu, Y., D. Zhang, J. Ping, S. Li, Z. Chen and J. Ma (2016) PLoS Genet. 12: e1005818.

Lu, S., X. Zhao, Y. Hu, S. Liu, H. Nan, X. Li, C. Fang, D. Cao, X. Shi, L. Kong et al. (2017) Nat. Genet. 49: 773-779.

Nan, H., D. Cao, D. Zhang, Y. Li, S. Lu, L. Tang, X. Yuan, B. Liu and F. Kong (2014) PLoS One 9: e97669.

Ping, J., Y. Liu, L. Sun, M. Zhao, Y. Li, M. She, Y Sui, F. Lin, X. Liu, Z. Tang et al. (2014) Plant Cell 26: 2831-2842.

Saindon, G., H.D. Voldeng, W.D. Beversdorf and R.I. Buzzell (1989) Crop Sci. 29: 1436-1439.

朱 江慧 - 徐 美蘭 - 竹島亮馬 - 針谷康平 - 山田哲也 - 阿部 純 (2017) 育種学研究 19（別 2）：49.

Sun, H., Z. Jia, D. Cao, B. Jiang, C. Wu, W. Hou, Y. Liu, Z. Fei, D. Zha and T. Han (2011) PLoS One 6: e29238.

Takeshima, R., T. Hayashi, J. Zhu, C. Zhao, M. Xu, N. Yamaguchi, T. Sayama, M. Ishimoto, L. Kong, S. Shi et al. (2016) J. Exp. Bot. 67: 5247-1036.

Thakare, D., S. Kumudini and R.D. Dinkins (2011) Planta 234: $933-$ 943.

Tian, Z., X. Wang, R. Lee, Y. Li, J.E. Specht, R.L. Nelson, P.E. McClean, L. Qiu and J. Ma (2010) Proc. Natl. Acad. Sci. USA 10: 8563-8568.

Tsubokura, Y., H. Matsumura, M. Xu, B. Liu, H. Nakashima, T. Anai, F. Kong, X. Yuan, H. Kanamori, Y. Katayose et al. (2013) Agronomy 3: 117-134.

Tsubokura, Y., S. Watanabe, Z. Xia, H. Kanamori, H. Yamagata, A.
Kaga, Y. Katayose, J. Abe, M. Ishimoto and K. Harada (2014) Ann. Bot. 113: 429-441.

Wang, Z., Z. Zhou, Y. Liu, T. Liu, Q. Li, Y. Ji, C. Li, C. Fang, M. Wang, M. Wu et al. (2015) Plant Cell 27: 323-336.

Watanabe, S., R. Hideshima, Z. Xia, Y. Tsubokura, S. Sato, Y. Nakamoto, N. Yamanaka, R. Takahashi, M. Ishimoto, T. Anai et al. (2009) Genetics 182: 1251-1262.

Watanabe, S., Z. Xia, R. Hideshima, Y. Tsubokura, S. Sato, N. Yamanaka, R. Takahashi, T. Anai, S. Tabata, K. Kitamura et al. (2011) Genetics 188: 395-407.

Watanabe, S., K. Harada and J. Abe (2012) Breed. Sci. 61: 531-543.

Wu, F.Q., E.J. Sedivy, W.B. Price, W. Haider and Y. Hanzawa (2017) Plant J. 90: 941-953.

Xia, Z., S. Watanabe, T. Yamada, Y. Tsubokura, H. Nakashima, H. Zhai, T. Anai, S. Sato, T. Yamazaki, S. Lü et al. (2012) Proc. Natl. Acad. Sci. USA 109: E2155-E2164.

Xu, M., Z. Xu, B. Liu, F. Kong, Y. Tsubokura, S. Watanabe, Z. Xia, K. Harada, A. Kanazawa, T. Yamada et al. (2013) BMC Plant Biol. 11: 152.

Xu, M., N. Yamagishi, C. Zhao, R. Takeshima, M. Kasai, S. Watanabe, A. Kanazawa, N. Yoshikawa, B. Liu, T. Yamada et al. (2015) Plant Physiol. 168: 1735-1746.

横田侑子・山田哲也 - 佐山貴司 - 加賀秋人 - 小木曽映里 - 石本 政男（2018）育種学研究 20（別 1）: 238 .

Zhai, H., S. Lü, S. Liang, H. Wu, X. Zhang, B. Liu, F. Kong, X. Yuan, J. Li and Z. Xia (2014) PLoS One 9: e89030.

Zhao, C., R. Takeshima, J. Zhu, M. Xu, M. Sato, S. Watanabe, A. Kanazawa, B. Liu, F. Kong, T. Yamada et al. (2016) BMC Plant Biol. 16: 20. 